\title{
Macroeconomic dynamics and the at-risk-of-poverty population in Slovakia
}

Ladislav Kabat

\section{Abstract}

This paper deals with analysis and presentation of the core findings under the EU SILC 2009 project. Particularly we are oriented on study of the socially vulnerable groups of population identified according their income situation. As a sorting criterion for this purpose we use the standard methodology set by OECD and Eurostat. It means the $60 \%$ of the national median equivalized disposable income is applied for this criterion as the poverty threshold. The national income variable is firstly calculated as a total income for each surveyed household and dived by the equivalized size of household. By this procedure the households of various structures are transformed onto generally accepted scale. The special attention of our study is oriented on the cluster of population living on income below the poverty threshold. For this population we calculate so called social deficit. Through this value we show the volume of financial means needed to upgrade the living standard of the population living bellow poverty threshold at least to the poverty threshold level.

Special section of the paper is devoted to study of relation among the core macroeconomic indicators (GDP per capita and GDP annual growth) and level and size of the at-risk-of-poverty population during the period of last economic development, including both economic growth and economic recession. According our tentative findings we did not find the significant impact of economic growth on the status of socially vulnerable population. This finding however should be studied in broader context, with longer time series of relevant data and with broader set of explanatory variables.

Keywords: poverty, social exclusion, at-risk-of-poverty population, poverty threshold, income median

JEL: I31, I32, I38

\section{Introduction}

Slovakia's economy experienced a period of significant growth in recent years. This development was interrupted only in the period of financial and economic crisis. Evaluation of this development is presented in many theoretical and practical studies. This paper focuses on analysis and presentation of the impact of economic growth on social development. Particularly we are concentrating on study of relation between GDP 
growth and changes in selected social indicators reflecting income situation of the Slovakian households. As a basic information source we use the macroeconomic data produced by Eurostat as well as the EU-SILC (1) project data.

The prime goal of this paper is to analyze the core social indicators generated by this project, particularly those measuring status of the bellow-at-risk-of-poverty households and individuals. The second goal is focused on identification and measuring the key economic determinants impact on the income and broader social situation of the households in Slovakia.

The EU SILC project is carried out since 2005 in all EU countries under a common methodological guideline of Eurostat. The last survey was conducted in Slovakia in April 2009. The objects of surveying were almost 6,000 households with more than 13,800 members ${ }^{1}$. Key variable collected and processed under this survey is the disposable income calculated per member of the household. Based on this information and according the Eurostat methodological guidelines the generalized income situation of the country's households is formulated and the core social indicators on the at-risk-of-poverty are calculated.

This outcome is a source of valuable information not only on the current income situation of the households in Slovakia, but given the real picture of the collected data it offers also additional information and indicators on the social status of the Slovakia's population.

The obtained data and derived information is of high value in assisting and guiding the social policies of national governments. Available microdata also provide a significant information source for a deeper statistical analysis of the income situation of observed households.

\section{The frame of the EU SILC project}

Statistical survey on Income and living conditions (EU SILC 2009) was implemented in the Slovak Republic under the project of European statistical surveys. The first statistical survey under this project was conducted in Slovakia in 2005. Through this project we obtain each year significant data on the population's income level and income differentiation. As a byproduct of processing this data we get also reliable information on poverty and social exclusion. This allows us to analyze in details the social situation of households in Slovakia as well as to compare it with the other European Union countries. This comparison is possible due to a single list of mandatory surveyed variables, implemented indicators and their definitions, statistical methods and the standardized calculations of basic indicators of poverty.

The EU SILC survey is carried out in Slovakia in the form of fieldwork in randomly selected households where interviewers collect requested data through questionnaires directly from their members. The result of processing this initial data is database - a set of data which are consequently used to calculate the basic social indicators, including poverty indicators and other statistical parameters of the income distribution function.

1) Information Reports, Statistical Office SR, Bratislava 1. July 2010 
Poverty indicators provide evidence of the structure and level of poverty at the national level. They create the basis for comparing living conditions in the European Union countries. At the national level, we use these data to keep track of various aspects of poverty - e.g. on terms of household composition, health, education, but also for calculation of other indicators linked to the poverty development over time.

The survey EU-SILC 2009 took place in April last year. Interviewers visited 5,988 selected households. Into our database we included 5,264 households with -16,137 persons. Data collection under this project was supported by active participation of the 395 interviewers who visited individual households in more than 300 villages and towns of Slovakia.

The basic information collected during this statistical survey is represented by the income variable. This value is calculated for all households and represents total income of all their members for particular year. Total income is further slightly recalculated in line with the Eurostat methodology. This procedure means that the total disposable income per households is divided by the equivalized size of these households. The equivalized size of households is done by the following formula - the first adult member of the household is counted by coefficient 1 , the second and all others adults are counted by coefficient 0.5 . All children below 14, economically not active, without their own income, are counted by factor 0.3 . This special calculation procedure is enabling to compare mutually the income situation of households of various size and structure. However this special size formulation procedure should be kept in mind whenever the final data is presented and interpreted for public.

The core studied variable is the disposable income variable defined as an income per equivalized member of household. Its mean and median values are used for further analytical studies on overall income situation. Particularly the share of the at-risk-of poverty population is estimated based on poverty threshold value calculated as $60 \%$ of the median value of respective income variable.

\section{What the first data of the EU SILC 2009 show?}

The basic information on the households' income situation for Slovakia show that mean value per person (equivalized) income per month was 524 Euros, with median value of 473 Euros. The highest mean values as well as the highest median values were reported for the Bratislava region with 682 and 609 Euros per month. In relative terms this means that mean of income variable in Bratislava region is more than $30 \%$ higher than the Slovak value. Respectively, the median value for Bratislava is about $29 \%$ higher than the Slovakia's value. Total figures are also showing that proportion of the population of Slovakia living at-risk-of-poverty reached $11 \%$, which is slightly higher level than it was in previous year. This finding could be attributed to the relatively high level of unemployment as well. (Table 1a. and Table 1b.)

According the EU-SILC 2009 results almost 11\% of Slovak citizens, it means more than 595,000 people, were at-risk-of-poverty. In terms of gender women are relatively more at-risk-of poverty status $(\mathbf{1 1 . 8 \% )}$ than men (10.1\%). Such high share of vulnerable people represents serious problem for the social policy programs. Table $\mathbf{2}$ presents the data on dynamics of the core indicators reflecting the level of poverty threshold recalculated for annual and monthly levels. 


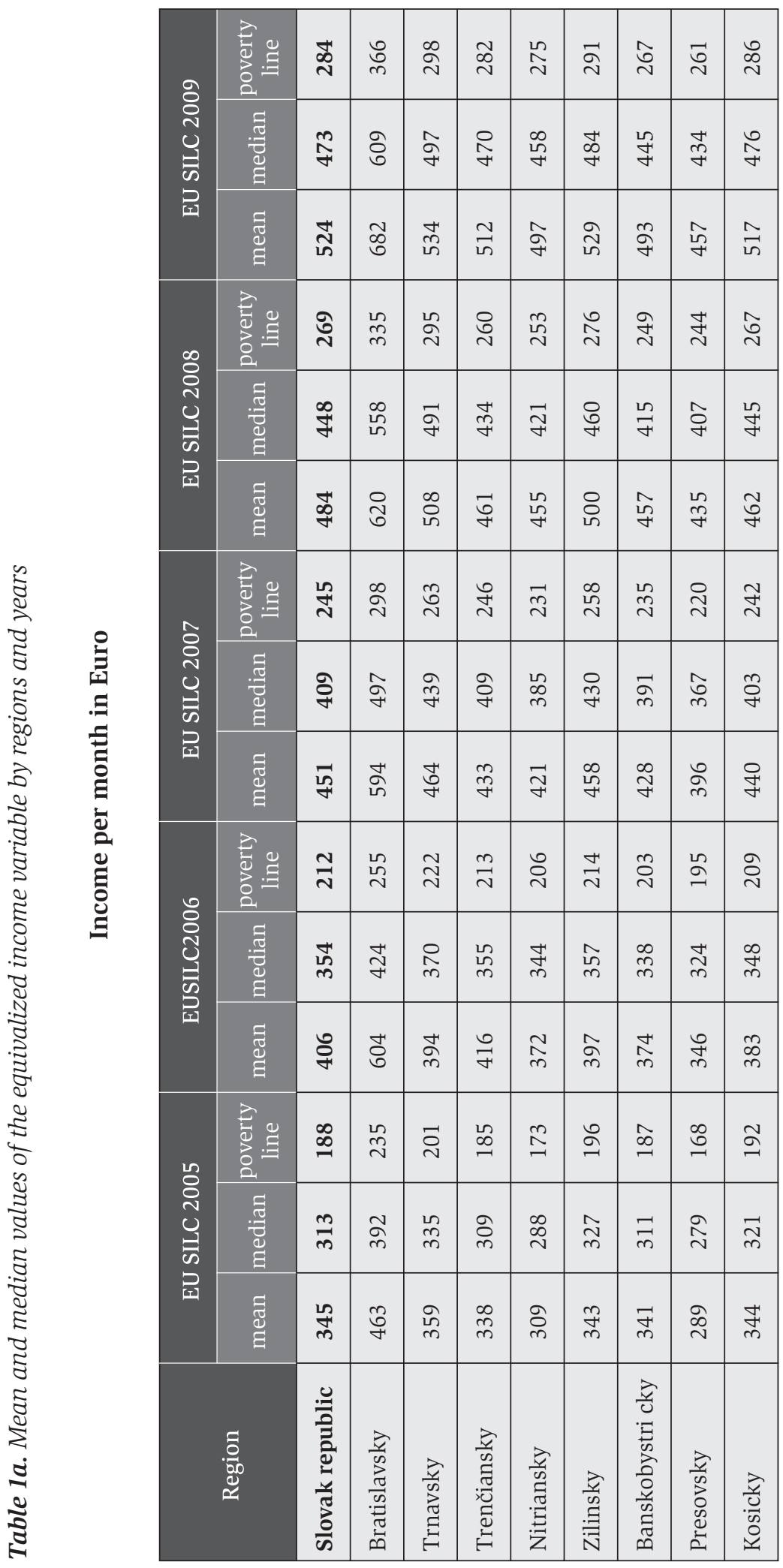




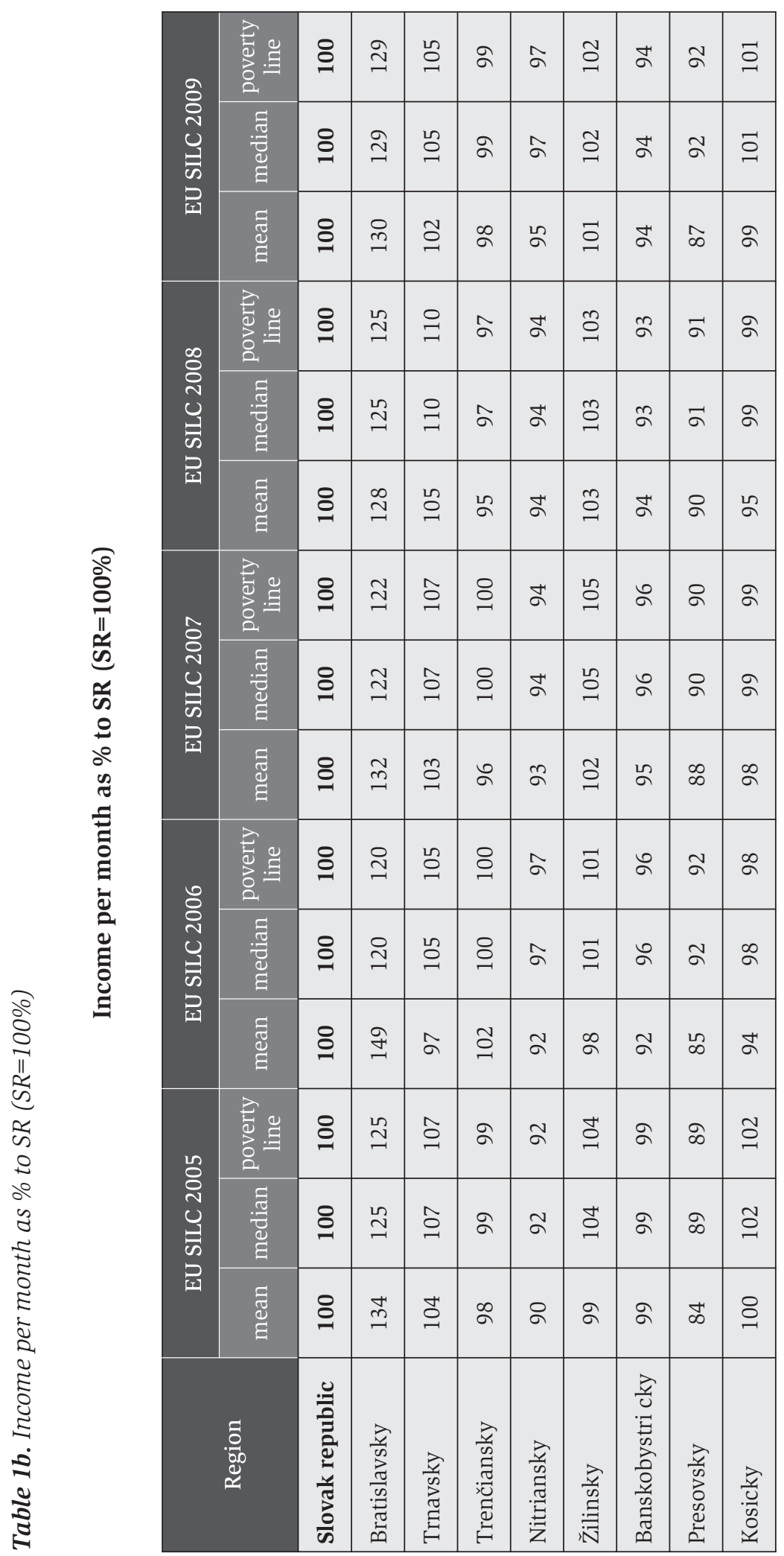


Table 2. At-risk-of-poverty thresholds by 2006-2009 EU-SILC data

\begin{tabular}{|l|c|c|c|c|}
\hline \multicolumn{1}{|c|}{ Indicator (per person) } & 2006 & 2007 & 2008 & 2009 \\
\hline Poverty threshold (Euros per year) & 2547 & 2944 & 3223 & 3403 \\
\hline Poverty threshold (Euros per month) & 212 & 245 & 269 & 284 \\
\hline
\end{tabular}

Data in this table are recalculated according the official exchange rate 1 Eur $=30,126$ Sk

An analysis of the at-risk-of-poverty presented below shows the significant factors influencing this situation. Some of them should be studied and analyzed in more details and broader context.

Concerning the type of the economic activity of respondents, the highest risk of poverty was identified for unemployed citizens - 48.6\%. The proportion of retirees at-risk-of-poverty was $8.9 \%$, the smallest proportion of population in this category was found among employed people (5.2\%), graph 1.

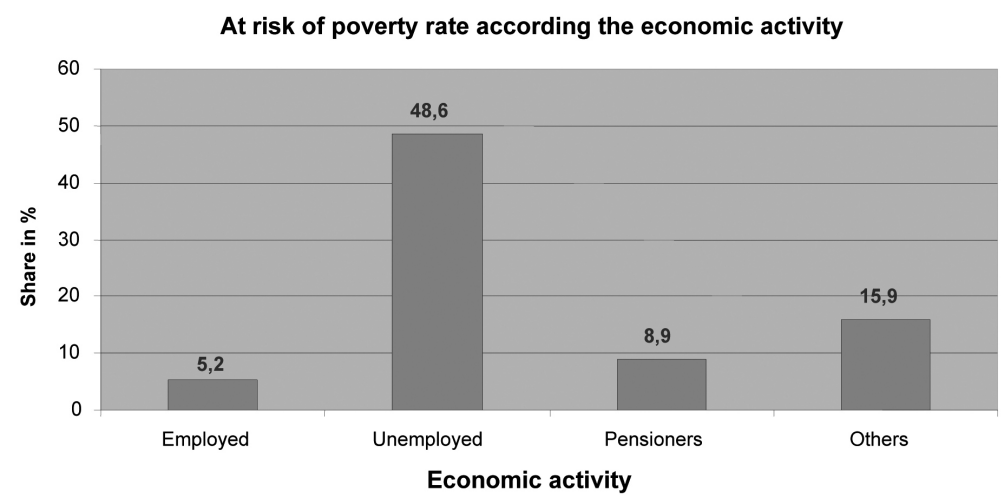

Graph 1. At-risk-of-poverty rate according the economic activity

Among the other important factors affecting significantly the income situation of households have been identified also the size and structure of the households. Particularly, incomplete families with children are reported as highly vulnerable groups. The most vulnerable ones are also those with 3 and more depending children (27.9\%), senior individuals (living alone) over 65 years (26.2\%) and single parents families with children (23\%), graph 2 .

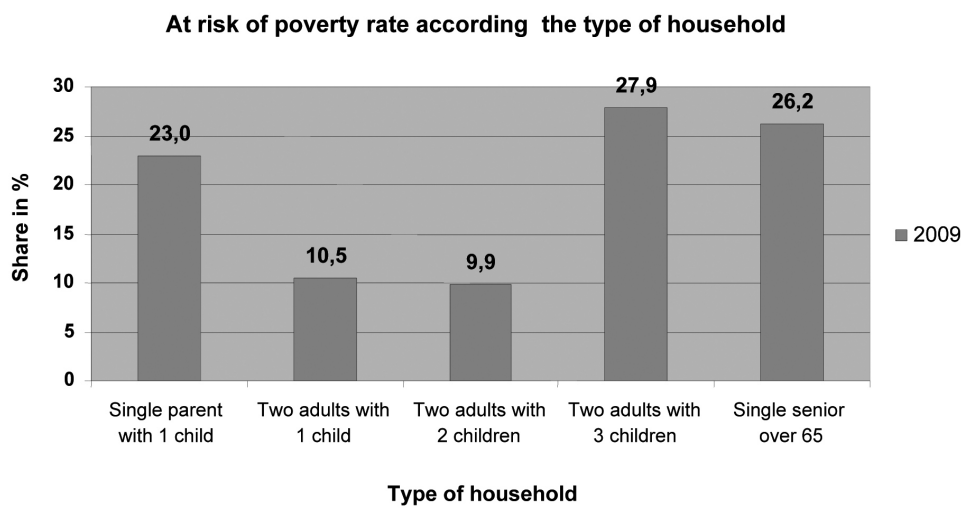

Graph 2. At risk of poverty rate according the type of households 
Threats to the population by income poverty require the long-term active involvement and support from the state. Without its programs and respective social transfers (pensions, survivors' benefits, sickness and invalidity compensations, payments in unemployment, various kinds of benefits and allowances for families with children), the risk of poverty rate according to EU-SILC 2009 data for Slovakia in 2009 would be over $\mathbf{3 5 . 9 \%}$. Taking into account the pensions and survivors' benefits, the share of those living at-risk-of-poverty was $\mathbf{1 7 . 1 \%}$.

The scope of this assistance can be illustrated also by comparing the proportion of vulnerable population before and after social transfers. As shown by graph 3 below, the active social support programs reduced the share of vulnerable households during 2006-2009 period annually by some $20 \%$. Such a high involvement of government is administratively very complicated and often also not fully transparent. This gives us an impetus to consider the new forms of assistance to disadvantaged (poor) people as well as to address the inadequacy of income through other instruments. A possible alternative may be the tool of the minimum pension, which is already discussed within the new Slovak government.

An overview of this development during the last years is presented on the Graph 3. below.

\section{At risk of poverty rate before social transfers}

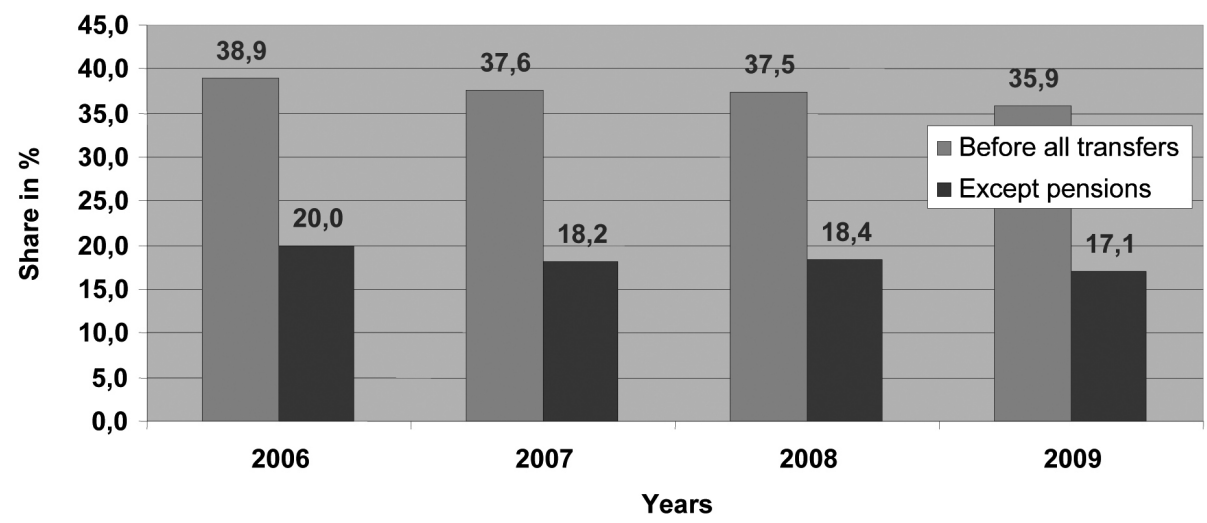

Graph 3. At risk of poverty rate before social transfers

The problem of social exclusion is a multidimensional social problem. Statistical variables collected under the EU SILC project clarify this problem only partially. It is therefore necessary to map the social situation of the population in the broader context and through more quantitative and qualitative indicators. The answers to the question How the household is able to make ends meet (to pay for its usual necessary expenses) on the scale ranging from 1-we are not able to live on this money to 5-easily are presented on Graph 4. As seen there are about 70\% of families reporting various levels of problems with living on their actual income.

This finding is rather interesting and should be analyzed and presented carefully. There is not quite clear consistency between relatively low share of the population identified in at-risk-of-poverty rate (11\%) and the high proportion of households reporting very basic and serious problems with their disposable finance. 


\section{Relative distribution of respondets according their ability to live with the actual income}

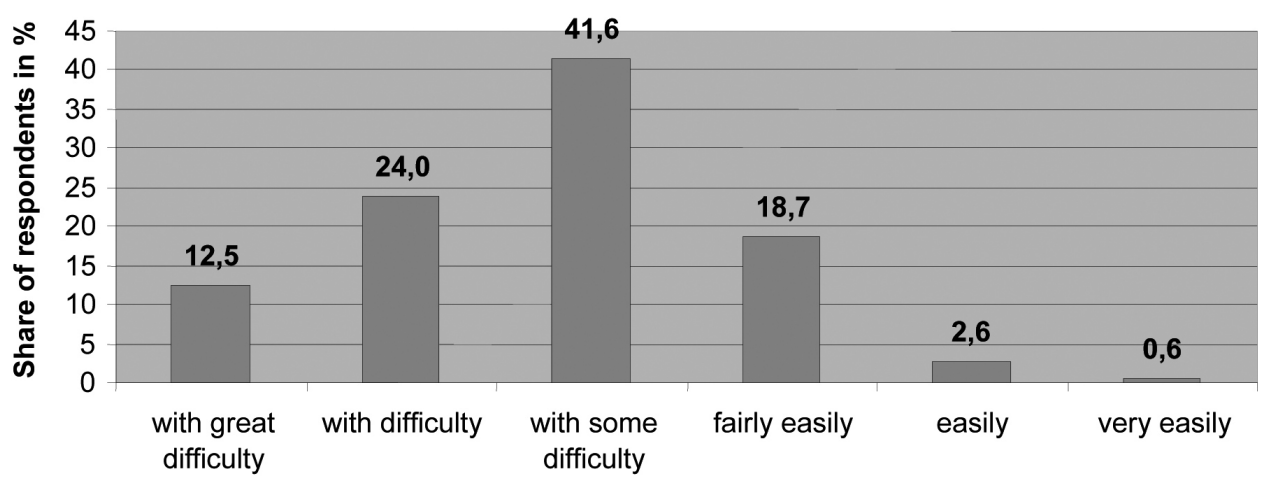

Classification

Graph 4. Relative distribution of respondents according their ability to live with the actual income

The further supplementary information on social, and particularly on material situation of households could be derived from the complex indicator Material deprivation rate. It is defined as follows : material deprivation rate is defined as the proportion of population with enforced lack of at least three (or four) out of nine following items, the household cannot afford: a) to face unexpected expenses, b) to go on one week annual holiday away from home, c) to pay for arrears (mortgage or rent, utility bills or hire purchase installments), d) to eat meal with meat, chicken or fish every second day, e) to keep home adequately warm, or could not afford (even if household wanted to): f) a washing machine, g) a color TV, h) a telephone and i) and a personal car.

The distribution of respondents is shown in table 3. Comparing this answer with the previous information we find that material deprivation is apparently much stronger, than the indicators of the income situation are showing.

Table 3. Material deprivation rate

\begin{tabular}{|c|c|c|c|c|c|}
\hline & 2005 & 2006 & 2007 & 2008 & 2009 \\
\hline 3 items & 43,2 & 35,7 & 30,2 & 27,8 & 24,5 \\
\hline 4 items & 22,5 & 18,3 & 13,7 & 11,8 & 11,1 \\
\hline
\end{tabular}

More detailed information on the rate of the at-risk-of-poverty households over last years is shown in the table 4 for various household structures. The long-lasting findings show that senior citizens as well as the young families with children and single parent families are the most vulnerable groups concerning their income situation. Surprisingly these groups of population demonstrate the long-lasting negative development of their income situation. Understandably, quite satisfactory development is reported by households of two adults and households without children. 
Table 4. At risk of poverty rate in various types of households

\begin{tabular}{|c|c|c|c|c|c|}
\hline $\begin{array}{c}\text { Type of } \\
\text { household }\end{array}$ & 2006 & 2007 & 2008 & \multicolumn{2}{|c|}{2009} \\
\hline \multirow[t]{4}{*}{ Person } & male & 19.6 & 15.3 & 19.0 & 19.6 \\
\hline & female & 15.7 & 17.9 & 22.5 & 24.5 \\
\hline & $<65$ & 19.1 & 18.2 & 21.5 & 20.0 \\
\hline & $65+$ & 14.8 & 16.4 & 21.9 & 26.2 \\
\hline Single parent & At least 1 child & 29.4 & 25.9 & 20.9 & 23.0 \\
\hline \multirow[t]{3}{*}{ Two adults } & 1 depending child & 8.0 & 5.9 & 9.6 & 10.5 \\
\hline & 2 depending children & 13.6 & 12.3 & 10.0 & 9.9 \\
\hline & $\begin{array}{l}3 \text { or more depending } \\
\text { children }\end{array}$ & 23.9 & 25.7 & 33.3 & 27.9 \\
\hline \multirow[t]{2}{*}{ Two adults } & Both $<65$ & 8.5 & 3.7 & 4.6 & 4.2 \\
\hline & At least one $65+$ & 4.1 & 3.9 & 3.6 & 3.5 \\
\hline \multirow[t]{2}{*}{ Households } & With depending child & 14.1 & 13.5 & 13.2 & 13.4 \\
\hline & Without depending child & 7.9 & 6.5 & 7.5 & 7.7 \\
\hline
\end{tabular}

\section{The selected macroeconomic data on EU and V4 countries and related social indicators}

There is a large spectrum of current economic literature dealing with measurement of relation between economic growth and living conditions of population. Various studies in this field are trying to identify the impact of economic growth expressed by GDP dynamic on living conditions and living standard of population. Over the last years, particularly over the economic crises, we can see strong increase in studies, which are seriously working on the new measurements of economic and social progress. The well known Stiglitz-Sen Report (2) is frequently referred in this context. Broader discussion on this topic could be also found in various additional sources, e.g. Kuznets (3), Eurostat (4), and Kabat (5).

Brief presentation of the basic macroeconomic indicators reflecting economic dynamics in EU and V4 countries with related indicators reflecting social development in these countries are presented in next part of our paper. Particularly we are interested in identifying relation between dynamics of GDP and dynamics of size of population classified in the at-risk-of-poverty income cluster.

Majority of EU countries, including countries of the Visegrad group, report for recent years (2005-2009) good results of their economic growth (6). As seen from table 4, these countries in 2005 reported their national GDP, when compared to the average of the EU between 51\% level in Poland and 87\% level in Slovenia with Slovakia's 60\% level. Also the annual increase of GDP in these countries was significantly higher than in old majority of EU member countries. This positive development was interrupted only by a period of financial and economic crisis as documented by data in the table 4 and graph 5 . 
Table 4. Basic macroeconomic data on the Visegrad countries

GDP per capita in PPS compared to EU average (EU $=100 \%)$

\begin{tabular}{|l|c|c|c|c|c|}
\hline & 2005 & 2006 & 2007 & 2008 & 2009 \\
\hline Country & 100 & 100 & 100 & 100 & 100 \\
\hline CR & 76 & 77 & 80 & 80 & 80 \\
\hline HU & 63 & 63 & 63 & 64 & 63 \\
\hline PL & 51 & 52 & 54 & 56 & 61 \\
\hline SR & 60 & 63 & 68 & 72 & 72 \\
\hline SLO & 87 & 88 & 89 & 91 & 86 \\
\hline
\end{tabular}

Real GDP Annual Growth in \%

\begin{tabular}{|l|c|c|c|c|c|}
\hline \multicolumn{1}{|c|}{ Country } & 2005 & 2006 & 2007 & 2008 & 2009 \\
\hline EU & 2 & 3,2 & 3,2 & 2,9 & $-4,2$ \\
\hline CR & 6,3 & 6,8 & 6,1 & 2,5 & $-4,1$ \\
\hline HU & 3,5 & 4,0 & 1,0 & 0,6 & $-6,3$ \\
\hline PL & 3,6 & 6,2 & 6,8 & 5,0 & 1,7 \\
\hline SR & 6,7 & 8,5 & 10,6 & 6,2 & $-4,7$ \\
\hline SLO & 4,5 & 5,8 & 6,8 & 3,5 & $-7,8$ \\
\hline
\end{tabular}

Source: Eurostat

As presented above, Slovakia achieved the highest GDP growth among these countries when comparing their economic dynamics to the European Union average. In the period 2005-2009 this GDP growth achieved almost 12\%, while in Czech republic it was only 4\%, in Hungary $0 \%$, Poland $10 \%$ and Slovenia reported even downfall of $-1 \%$.

\section{Dynamics of GDP in V4 to EU (EU=100\%)}

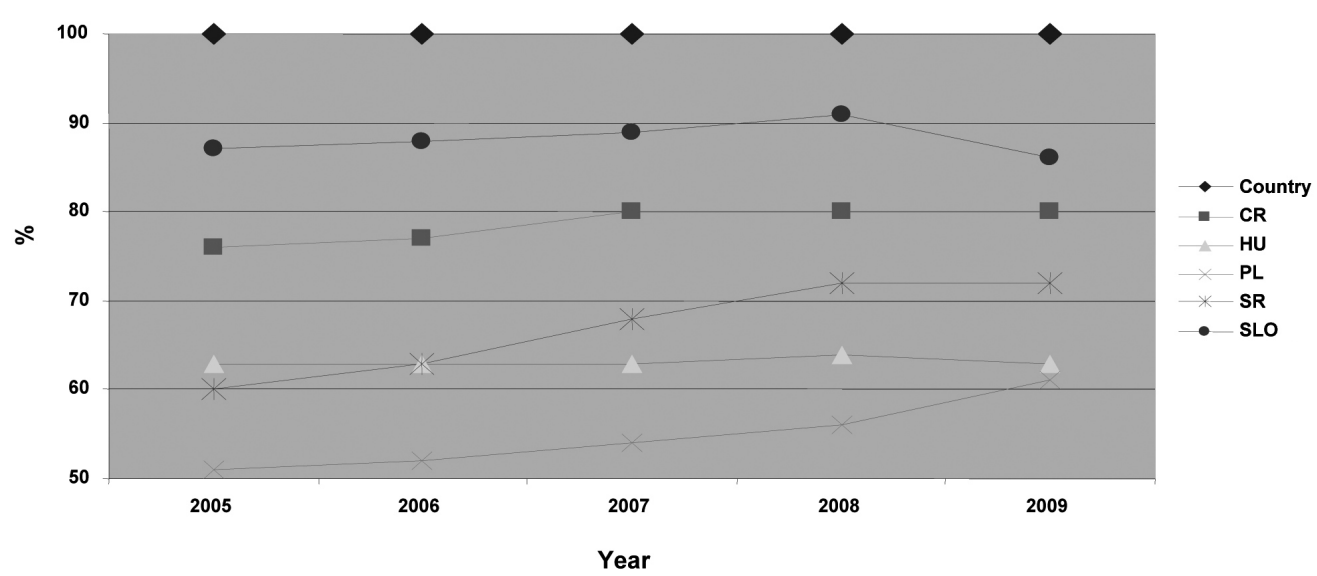

Graph 5. Dynamics of GDP in V4 compared to EU average data 
Cumulative GDP growth of Slovakia reached during the referred period more than $27 \%$. This was due to the previously well-set macroeconomic policy, relatively rational fiscal policy and generally improved entrepreneurial environment. As a positive factor the Slovakia's international position and its attractiveness to foreign investors should be noted too.

The presented data on economic performance of Slovak economy show relatively well functioning economic system. However, the goal of our paper is to go deeper with analysis of the EU SILC indicators and their relation with those reflecting economic growth. Particularly we are interested in identifying the impact of economic growth on the situation of the at-risk-of-poverty population (7). For this purpose we study three groups of the surveyed households.

The first one is the at-risk-of-poverty population before all social transfers (PBAST), while the second group is represented by the at-risk-of-poverty population before social transfers except the pension payments (survivors and old-age benefits) (PBSTEPP). The third group is represented by the at-risk-of-poverty population identified in case, when the disposable income variable is applied. Because of the short time series, we cannot derive the relevant regression functions enabling us to analyze correctly the relation between GDP growth and changes in the size of all these groups. However, as shown on the graph 6 these data indicate relatively low impact of the economic growth presented by GDP per capita and at-risk-of-poverty population.

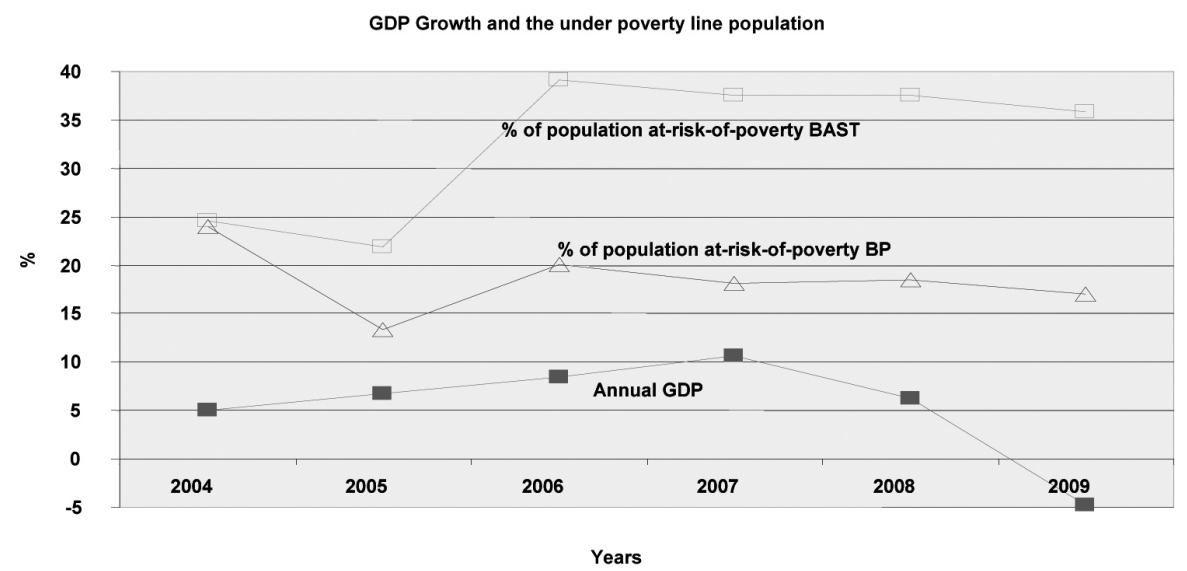

Graph 6. GDP Growth and the at-risk-of-poverty population dynamics

By considering the additional explanatory data we can find that the vulnerable groups of population are in "relatively safe" status mostly due to various social supporting schemes (8).For 2006-2009 period they reached relatively high level (in \% of GDP) it was:

\begin{tabular}{|l|l|l|l|l|l|}
\hline Social contributions & 12.8 & 11.9 & 11.8 & 12.1 & 12.8 \\
\hline
\end{tabular}

This situation could be related to the relatively strong position of the country's trade union and close relation with the previous left oriented government. Generally, the above presented results have not proved the direct positive impact of the economic growth on the proportion of the socially excluded population in Slovakia. This partial finding however should be studied under the broader frame of explanatory variables and also under the longer time span. 


\section{EU SILC data and the social policy impact studies}

The results obtained under the EU SILC project have clear interpretation and possible application in social policy studies. As shown on the scheme below it is useful to expand our study out of the standard at-risk-of-poverty indicators. Significant contribution in poverty studies has been done by the Nobel Prize winner A. Sen (9). He focused his study on the theoretical distribution of the income variable. He studied in details the left tail of this distribution, which represents actually the bellow-at-risk-of-poverty threshold population. According Sen the study of theoretical distribution of the income variable should continue with more elaborated analysis of the population living bellow poverty threshold. To clarify and quantify this study he introduced a concept of the depth of poverty. The depth of poverty was defined as a difference between values of poverty threshold and income average bellow poverty threshold (A-a). This value in financial terms shows the income deficit of the average individual (household) classified in at-risk-of-poverty cluster needed for pulling this household up to poverty threshold - at least. See picture 1 .

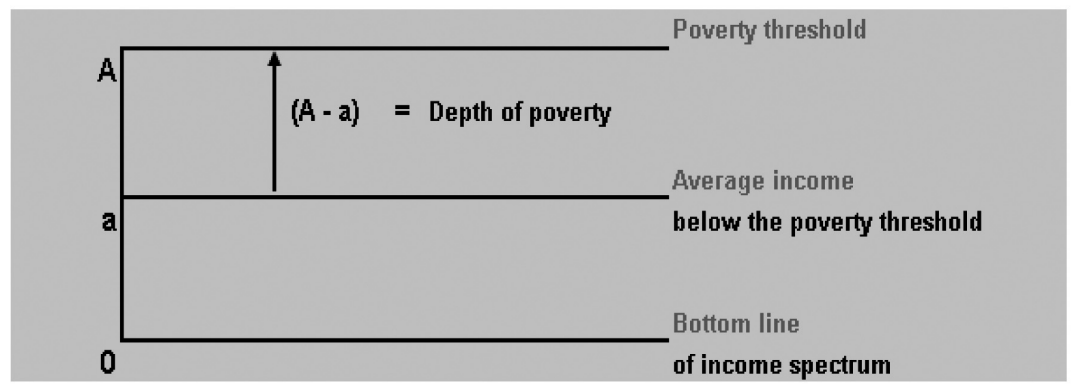

Picture 1. The Sen's study on the bellow-poverty study

Based on this we an estimate the total social deficit in financial terms needed to assist the entire set of needed people to upgrade their income situation to the poverty threshold level. The aggregated social deficit for entire population (N-risk) living at the risk of poverty status could be calculated by following formula:

$$
\text { SD1 }=(\mathrm{A}-\mathrm{a}) *(\mathrm{~N}-\text { risk })
$$

represents the monthly (annually) needed financial support to pull-up the income situation of the single citizen from the below-poverty threshold status to the at-the poverty level situation. The below presented table demonstrates the calculation of total social deficit for entire cluster of population living bellow poverty threshold with the (A-a) depth-of-poverty. The final calculation is made -as an illustration- for one month and one year for Slovakia for the last consecutive years.

Table 5. Poverty indices and social income deficit estimates

\begin{tabular}{|c|c|c|c|c|c|c|c|c|c|}
\hline \multirow{2}{*}{ Year } & \multicolumn{3}{|c|}{ Population } & \multicolumn{2}{c|}{ Poverty } & $\begin{array}{c}\text { Scope of } \\
\text { poverty }\end{array}$ & $\begin{array}{c}\text { Index } \\
\text { of Depth }\end{array}$ & Monthly & Annually \\
\cline { 2 - 11 } & $\begin{array}{c}\text { Total } \\
(000)\end{array}$ & $\%$ at risk & abs (000) & $\begin{array}{c}\text { Poverty } \\
\text { threshold }\end{array}$ & $\begin{array}{c}\text { Mean } \\
\text { income }\end{array}$ & A-a & (A-a)/A & in millions euro \\
\hline 2006 & 5400 & 11,6 & 626,4 & 212 & 157 & 55 & 0,259 & & \\
\hline 2007 & 5400 & 10,5 & 567,0 & 245 & 182 & 63 & 0,257 & & \\
\hline
\end{tabular}




\begin{tabular}{|c|c|c|c|c|c|c|c|c|c|}
\hline \multirow{2}{*}{ Year } & \multicolumn{3}{|c|}{ Population } & \multicolumn{2}{c|}{ Poverty } & $\begin{array}{c}\text { Scope of } \\
\text { poverty }\end{array}$ & $\begin{array}{c}\text { Index } \\
\text { of Depth }\end{array}$ & Monthly & $\begin{array}{c}\text { Annuall } \\
y\end{array}$ \\
\cline { 2 - 11 } & $\begin{array}{c}\text { Total } \\
(000)\end{array}$ & $\%$ at risk & $\begin{array}{c}\text { abs } \\
(000)\end{array}$ & $\begin{array}{c}\text { Poverty } \\
\text { threshol } \\
\text { d }\end{array}$ & $\begin{array}{c}\text { Mean } \\
\text { income }\end{array}$ & A-a & (A-a)/A & in millions euro \\
\hline 2008 & 5400 & 10,9 & 588,6 & 269 & 198 & 71 & 0,264 & & \\
\hline 2009 & 5400 & 11,0 & 594,0 & 284 & 202 & 82 & 0,289 & & \\
\hline
\end{tabular}

The calculation of the social income deficit of the bellow-at-risk-of-poverty population is the first necessary step in dealing with the poverty problem. The next steps should be linked to the government social policy programs.

\section{Conclusions}

Based on the reported outcomes of the EU-SILC project we found that the core social problems of Slovakia - particularly relatively high share of unemployed population and share of socially vulnerable population has not changed significantly during the period of strong economic growth in Slovakia. We did not prove either the direct positive impact of economic growth determinants on dynamics of social development. This finding however should be studied in more details and taking into account longer time series on relevant statistical data as well as the broader set of explanatory variables.

\section{References}

Eurostat: Combating Poverty and Social Exclusion, 2010

Stiglitz, J., Sen, A., Fittoussi, J., P.: Report by the Commission on Measurement of the Economic Performance and Social Progress, Brussels-Paris, 2009

Kuznets, S.: National Income, 1929-1932" . 73rd US Congress, 2d session, Senate document no. 124,1934

Eurostat: Beyond GDP-Measuring Progress, True Wealth and the Well-being of Nations, International Conference, November 19-29, Brussels, 2007

Kabát, L.: Analýza a meranie príjmovej situácie slovenských domácnosti v rámci projektu EU SILC, Štatistika a demografia, Bratislava, 2007

Eurostat: Government Finance Statistics, Data 1996-2009, Brussels, 2010

Kabát, L.: Nové prístupy k meraniu výsledkov ekonomického rastu a sociálneho rozvoja, in Firma a konkurenční prostředí, Mendlova univerzita Brno, 2009

MPSVaR: Programové vyhlásenie vlády SR, august 2010

Sen, A.: Conceptualizing and measuring poverty, in \&poverty and Inequality, edited by D. Grusky and R. Kanbur, Stanford University Press, California, 2006

prof. Ladislav Kabat,

dean of Faculty of Economy and Business, Pan - European University

Tematínska 10, 851 05, Bratislava, Slovakia, phone: 02/68203606,E.mail: ladislav.kabat@uninova.sk 